Aletria, Belo Horizonte, v. 30, n. 4, p. 331-334, 2020

(c) $\underset{\mathrm{BY}}{(\mathbf{i}}$

\title{
MOREIRA, José Pedro. Porque canta um pequeno coração. Lisboa: não (edições), 2019.
}

Paulo Rodrigues Ferreira

Universidade da Carolina do Norte em Chapel Hill (UNC), Chapel Hill, Carolina do Norte / Estados Unidos

paulorf@email.unc.edu

http://orcid.org/0000-0002-6698-0860

No seu mais recente livro, Porque canta um pequeno coração, publicado pela não (edições), editora independente portuguesa, José Pedro Moreira, autor formado em Estudos Clássicos que trabalha como editor em Inglaterra e se destacou com as traduções de Ésquilo e de Catulo para português, apresenta-nos um conjunto de poemas que é também um repositório de paisagens e de pessoas, de desabafos sobre a rotina comezinha que recorrentemente evoluem para reflexões de pendor filosófico acerca do sentido da vida, do amor e da amizade. A sua veia classicista está presente em cada página, não apenas pelas múltiplas referências a poetas e a autores clássicos ou pelas alusões a deuses e a mitos greco-romanos, mas também por a todo o momento tropeçarmos em ensinamentos, mitos e parábolas que, talvez com o intuito de produzir sátira, se cruzam com lugares periféricos da região de Lisboa, como o Feijó e a Trafaria, e nos parecem querer ensinar algo sobre esta nossa absurda condição humana. Em Porque canta um pequeno coração sobressaem também figuras minúsculas, caricaturais, como certos jovens escritores portugueses, insuportavelmente ambiciosos, dispostos a vender a alma ao diabo a troco de uma publicação em revista literária ou de um aperto de mão a alguém famoso. Ao jeito de um Montaigne contemporâneo com menos pretensão e densidade intelectual, José Pedro Moreira escreve sobre amigos e conhecidos, sobre figuras patuscas que perderam a alegria em garrafas de cerveja, sobre diálogos passados em 
bares e tascas, sobre viagens e experiências na Europa, conta histórias sobre tias burguesas e outros familiares falecidos. Há ainda espaço neste livro para meditações sobre Thom Yorke e outras relíquias musicais não menos depressivas do que Radiohead, e que fizeram parte do seu imaginário na adolescência, nos inícios do século. Ao longo destas mais de cento e quarenta páginas, ressalta um sabor do passado, as referências a um tempo mítico em que o efebo caminhava de Walkman e pensava nas namoradas, as velhotas passeavam pela cidade com penteado castiço, e nos cafés os adeptos do Benfica, embebedados com as derrotas no futebol, rachavam mesas aos murros.

Longe de ser um poeta lírico que nos pretenda arrebatar pela beleza estética ou pela riqueza vocabular, José Pedro Moreira destacase pela sagacidade e humor com que, no mesmo poema, perora sobre questões aparentemente tão desconexas como a preparação do presunto de Parma e a maturação de um manuscrito inédito trancado na gaveta. No poema "Notas sobre o Prosciutto di Parma", começamos com uma longa (e até exagerada) descrição desse processo de preparação do presunto, para chegarmos à parte em que o poeta, sempre apegado aos autores que contribuíram para a sua formação acadêmica e intelectual, nos revela que "Horácio instrui o jovem Pisão / a deixar as suas composições poéticas / curar numa gaveta bem condicionada / durante nove longos anos / depois de escolhidas / e doutamente tratadas / por um crítico judicioso"(p. 17). Estabelecendo paralelismos com a carne de porco que evolui para iguaria dispendiosa, também ao manuscrito engavetado sucedem fenómenos miraculosos, "texturas que se desfazem / refazem e intensificam / através de fenómenos de proteólise e lipólise" (p. 15). Num tom comedidamente humorístico, em que se faz menção a meninos de boas famílias e a imberbes poetas ambiciosos alimentados pelo sonho da glória, José Pedro Moreira transforma este poema sobre presuntos numa aproximação à sabedoria clássica e aos ensinamentos para a vida. Para sermos mais concretos, alerta-nos para o valor da cautela: "não ponhas fotografias do pirilau na net / meu rapaz / senão ainda te vês atrapalhado daqui a uns anos" (p. 17). Como o presunto que precisa maturar, o melhor que o poeta tem a fazer é deixar as coisas levarem o seu tempo.

Tópicos centrais neste livro são a emigração, a separação física dos locais a que noutras encarnações o poeta se afeiçoou, a nostalgia crescente que o leva a revirar os mais variados recantos do mundo sem arribar ao centro procurado, ou ao sítio onde se iniciou aventura 
heroica que prometia abundância e realização pessoal. Em "AkiPort Café", perpassa o tom nostálgico com que se conta a história de homens que, trinta anos depois, regressam ao seu país para mergulharem numa realidade de tascas e de "pastéis de nata", de "Superbocks", de preces à "nossa senhora", de "bigodes farfalhudos" que lembram o "fantasma do Bento / majestoso e respeitável" (p. 31). Para além desse cenário lisboeta pintalgado de chulos, talhantes e criaturas desejosas de reviver momentos de descomprometida alegria, ressaltam os poemas em que amizade é o tema principal. Por exemplo, em "Da amizade", "uma editora e um contabilista / ambos húngaros / uma poeta e outro editor / ambos portugueses / encontram-se num pub / na noite de passagem de ano" (p. 39). E inegável que existe uma forte carga autobiográfica nestes poemas repletos de editores e de poetas que se entretêm cantando, contando anedotas e solitariamente ingerindo bebidas alcóolicas nos mais variados estabelecimentos subterrâneos europeus. Contudo, ao contrário do que se poderia pensar, esta poesia que às vezes se nos afigura mundana e limitada no que toca à beleza estética, ganha precisamente por remeter para um passado imemorial, para frases oriundas de outros tempos, ditas por vozes familiares que morreram na infância e que voltam a ser repetidas pelos amigos do presente: "a minha vida foi salva / mais vezes do que merecia / por amor / e amizade" (p. 40). Uma das grandes virtudes do livro é, aliás, a capacidade de a cada poema iluminar uma passagem arquivada na memória, uma frase que nos relembra momentos quase extintos, como os namoricos nos corredores da escola secundária, do marialva que distribuía sopapos, da tia e da avó que nos encantavam com sua sabedoria saloia.

Porém, se crítica pudesse ser feita a este livro seria a de que o seu autor não vai além do registo da racionalidade, das recordações, e tal atrasa a progressão da escrita, não lhe permite atravessar caminhos nunca antes percorridos. Em The Undiscovered Self (2010), observou Carl Jung que, embora a maior parte das pessoas confunda autoconhecimento com o conhecimento do ego, esse, sempre ignorante, conhece apenas o que é visível dentro de si, não o conteúdo do subconsciente. Partindo desta procura daquilo que dorme no subconsciente, concluiria dizendo que ao poeta falta quebrar fórmulas e convenções que o impedem de desfrutar do chamado texto de gozo de que falava o crítico Roland Barthes (1975), que é uma escrita que vai para lá do prazer, que rompe fronteiras, que rasga as tradicionais formas de escrever burguesas, que nos confronta 
com a essência da condição humana, com aquilo que se aproxima daquela verdade primitiva acerca de nós mesmos que nos parece sempre distante e que nos surge, mesmo que raras vezes, em forma de verso ou de frase. Esse trabalho de ultrapassar o conhecido, aquilo que a razão sabe e que a memória lembra, é algo a que o autor de Porque canta um pequeno coração pode almejar se quiser atingir a excelência da escrita. Afinal de contas, como escreveu Herberto Helder na introdução a Uma faca nos dentes, de António José Forte, "toda a verdadeira poesia assenta na sua própria dificuldade” (1983, p. 7).

\section{Referências}

BARTHES, Roland. The Pleasure of the Text. New York: Farrar, Strauss and Giroux Inc., 1975.

HELDER, Herberto. Nota Inútil. In: FORTE, António José. Uma faca nos dentes. Lisboa: \& Etc, 1983. p. 1-8.

JUNG, Carl. The Undiscovered Self. New Jersey: Princeton University Press, 2010.

Recebido em: 26 de novembro de 2020.

Aprovado em: 11 de dezembro de 2020. 